DOI: 10.5824/1309-1581.2018.1.008.x

http://www.ajit-e.org/?menu=pages\&p=details_of_article\&id=67

Received : 11.10.2017 Editorial Process Begin: 17.10.2017 Published: 12.02.2018

\title{
Akademisyenlerin Mobil İnternet Tercihini Etkileyen Davranışsal ve Demografik Faktörler
}

\begin{abstract}
Halim Tatlı, Bingöl Üniversitesi., iktisadi ve Idari Bilimler Fakültesi., htatli@bingol.edu.tr, https://orcid.org/0000-00027940-0087
\end{abstract}

Fuat Alaca, Bingöl Üniversitesi., iktisadi ve Idari Bilimler Fakültesi., falaca@bingol.edu.tr, https://orcid.org/0000-00020470-8474

ÖZ Bu araştırma, akademisyenlerin mobil internet tercihini etkileyen davranışsal ve demografik faktörleri değerlendirmek amacıyla yapılmıştır. Kesitsel nitelikte ve analitik olan araştırma, Bingöl üniversitesinde görev yapmakta olan 300 akademisyenin tümü üzerinde gerçekleştirilmiştir. Veri toplama aracı olarak Kişisel Bilgi Formu ve Teknoloji Kabul Modeli kullanılmıştır. Bu anket, KasımAralık 2015 tarihlerinde uygulanmıştır. Mobil internet tercih alt ölçekleri içinde "yakınsama" ölçeğinin ortalama puanı en yüksek, "İmaj" alt ölçeğinin ortalama puanının en düşük olduğu tespit edilmiştir. Erkek akademisyenler kadın akademisyenlerle kıyaslandığında anlamlı olarak algılanan kullanışlılı̆̆a daha fazla önem verdikleri saptanmıştır. Akademisyenlerin yaşı artıkça mobil internet tercihinde algılanan kullanışlılı̆̆a, algılanan kullanım kolaylı̆̆ına, kullanım tutumuna ve yakınsamaya anlamlı olarak daha fazla önem verdikleri saptanmıştır. Gelir ve algılanan kullanım kolaylı̆̆ı, kullanım tutumu ve yakınsama alt ölçeklerinin puan ortalaması arasında istatistiksel olarak anlamlı bir ilişki olduğu saptanmıştır. Ayrıca algılanan kullanım kolaylı̆̆ı ile algılanan kullanışlılık, kullanım tutumu ve yakınsama ölçekleri arasında kuvvetli ve pozitif yönlü bir ilişki olduğu bulunmuştur. Sonuç olarak, akademisyenlerin mobil internet tercihini olumsuz etkileyen faktörlerin iyileştirmesi için gerekli önlemlerin alınması gerektiği kanaatine varılmıştır.

Anahtar Kelimeler: Mobil internet, davranıssal faktörler, demografik faktörler, teknoloji kabul modeli, Bingöl Üniversitesi

\section{Behavioral and Demographic Factors Affecting Academicians' Mobile Internet Preference}

\begin{abstract}
This study has been carried out with the aim of assessing academicians' behavioral and demographic factors that affected mobile internet preferences. Being cross-sectional and analytical, the study was carried out all of 300 academicians who were working at Bingöl University. As a means of data collection, Personal Information Form and Technology Acceptance Model have been used. This questionnaire was implemented between November and December 2015. It was determined that the average score of the "convergence" scale was the highest and the average score of the "image" subscale was the lowest among the mobile internet preference subscales. When male academicians compare to female academicians, they have been found a significantly to give more importance to perceived usefulness. As the age of academicians increases, they were found to be significantly more important the perceived usefulness, perceived ease of use, intention to use and convergence in the mobile internet choice. It was found that there was a statistically significant relationship between income and the
\end{abstract}


average of the perceived ease of use, the intention to use and the convergence subscales. In addition, it was found that there was a strong positive correlation between the perceived ease of use and the perceived usefulness, the intention to use and the convergence subscales. As a conclusion, it is recommended that the necessary precautions should be taken to improve the factors negatively affecting the mobile internet preference of the academicians.

Keywords: Mobile internet, behavioral factors, demographic factors, technology acceptance model, Bingol University

\section{GİRIŞ}

Bilgi ve iletişim teknolojilerinde meydana gelen gelişmeler sonucunda akıllı telefon ve akıllı cihazların kullanımı giderek daha yaygın hale gelmiştir. Bu cihazların daha yaygın bir biçimde kullanılmasının nedeni gelişmiş işletim sistemlerine sahip olmaları, kullanımlarının kolay olması, kullanıcılarına yeni uygulamaları yüklemelerine imkan tanıması ve mobil internet vasıtasıyla sürekli internete bağlı olmalarına imkan vermesidir. Mobil internet üzerinde sunulan ve insan yaşamını kolaylaştıran hizmetler arttıkça ona olan ilgi de artmaktadır. Mobil internet mobil ve akıllı cihazlar üzerinden internet içeriğine kablo olmadan erişim olarak tanımlanmaktadır (Vlachos ve Vrechopoulos, 2008). Mobil internet, yönlendirici, telefon hatt1 ya da kablo gibi aracilar olmadan mobil cihazlar (küçük laptoplar, mobil telefonlar, akılı telefonlar, cep bilgisayarları, USB modemler ve USB stickleri) üzerinde kablosuz internet bağlantısı olarak tanımlanabilir. Mobil internet bağlantısı 3G, 4G veya 4.5G gibi mobil akıllı telefon şebekeleri aracılığıyla yapılır.

Günümüzde mobil internet çok farklı kullanım alanlarına sahiptir. Zira mal ve hizmetleri satınalma, eğitime erişme, iletişim sağlama, finans, bilgi edinme, eğlence, sosyal etkileşim vb. birbirinden çok farklı ihtiyaçlara mobil internet vasıtasıyla erişilmektedir. We Are Social ve Hootsuite tarafından küresel ölçekte yapılan çalışmanın sonuçları “Digital in 2017 Global Overview" raporunda yayınlanmıştır. Bu çalışmanın sonuçlarına göre dünyanın yarısından fazlası artık en az bir adet akıllı telefon kullanmakta, dünya nüfusunun üçte ikisi en az bir cep telefonu sahibi ve dünyanın dört bir yanındaki mobil bağlantıların yarısından çoğu artık "genişbant" kullanmaktadır (We Are Social, 2017). Türkiye'de 2016 yılı sonunda toplam 62.2 milyon geniş bant internet abonesinin 51.7 milyonu mobil internet abonesi olup, internet abonesi artışındaki en büyük paya sahip (yaklaşık \%34.8) internet türü mobil cepten internettir (Bilgi Teknolojileri ve İletişim Kurumu, 2017). Araştırmanın yapıldığı Bingöl ilinde ise 2014 yılında 97450 olan mobil genişbant internet abone sayısı, yaklaşık \%57 oranında artarak 2016 yılında 153068 kişiye ulaşmıştır (Bilgi Teknolojileri ve İletişim Kurumu, 2017). Bu istatistikler, gün geçtikçe mobil internetin birçok bireyin yaşamında önemli yer tutacağını göstermektedir. Bu nedenle mobil internetin kullanım özelliklerinin davranışsal boyutta neler olduğunu ve bu özeliklerin demografik faktörlerle ilişkisinin ortaya konulması önemli hale gelmektedir.

$\mathrm{Bu}$ çalışmanın temel amacı giderek günümüz insan hayatının vazgeçilmezi haline gelen mobil internetin tercihinde etkili olan davranışsal ve demografik faktörleri araştırmak ve kullanım davranışı ile kullanıcı demografik özelikleri arasındaki ilişkiyi incelmektir. Çalışma, beş bölümden oluşmakta olup, ikinci bölümde literatür özetine, üçüncü bölümde çalışmanın materyal ve 
yöntemine yer verilmiştir. Dördüncü bölümde analizden elde edilen bulgular özetlenmiş ve yorumlanmıştır. Beşinci ve son bölümde ise araştırmanın sonuçları değerlendirilmiş ve politika önerilerinde bulunulmuştur.

\section{Literatür taraması}

Literatür incelendiğinde konu ile ilgili yurt dışında daha fazla çalışma yapıldığ yurt içinde ise sınırlı sayıda çalışma bulunduğu görülmektedir. Bu çalışmalar mobil internet kullanımı, tüketicilerin mobil internet servislerini benimsemesi ve hizmet kalitesi üzerinde yoğunlaşmaktadır. Yeni teknolojilerin seçiminde davranışsal boyutlar araştırılırken kullanılan modelin asıl adı Technology Acceptance Model (TAM) olan Teknoloji Kabul Modelidir (TKM) (Ramirez-Correa vd. 2015). Bu bağlamda Klein ve Koenigstoter (2007) mobil internetin sunduğu hizmetlerin benimsenmesini belirlemek için teknoloji benimsenme modelini kurmuşlardır. Yapılan analizde kişisel yenilikçilik, kullanışlılık ve kendini ifade etme olgularının mobil internetin benimsenmesinde önemli olduğunu tespit etmişlerdir. Benzer şekilde Roostika (2012) üniversite öğrencileri, üzerinde yaptığı çalışmasında kullanışlılık ve haz almanın mobil internetin benimsenmesinde etkili olduğunu tespit etmiştir. Yapılan bir başka çalışmada mobil internet servislerinin bilgi kalitesi, teorik bir model üzerinde ampirik olarak incelenmiştir (Chea vd.: 2002). Söz konusu çalışmada artan tüketici memnuniyeti ve sadakati ile internet servislerinin bilgi kalitesi arasında anlamlı bir ilişki bulunmuştur. Lee vd. (2002) tarafından Kore'de yapılan araştırma sonuçlarına göre kullanım kolaylığı, kullanışlılık, sosyal etki ve öz-yeterlilik unsurlarının mobil genel ağ uygulamalarının kullanımında önemli olduğu tespit edilmiştir. TAM modeline dayalı bir diğer çalışma Smith vd. (2013) tarafından öğrenciler üzerinde yapılan çalışmadır. Söz konusu çalışmada Norveç, Almanya ve Amerika'da çevrimiçi alış veriş davranışını etkileyen kültürel etmenler incelenmiştir. Çalışmada yapılan analiz sonucunda bilişsel katılımın algılanan kullanışlığı her ülkede anlamlı bir biçimde etkilediği tespit edilmiştir.

Bazı çalışmalarda, öğrencilerin genel olarak internet kullanım özeliklerinin neler olduğu ve bu etmenleri etkileyen faktörler incelenmiştir. Nitekim Jenaro vd. (2007), Salamanca Üniversitesi'nde öğrenim gören 337 öğrenci üzerinde yaptıkları anket çalışması sonucunda elde edilen veriler ile lojistik regresyon analizini yapmışlardır. Bu analiz sonuçlarına göre öğrenciler arasında internet kullanımının yüksek kaygıyla ilişkili olduğu bulunmuştur. Jones vd. (2009), öğrencilerin internet kullanımlarını tespit etmek için Amerika Birleşik Devletleri'nde (ABD) 7421 üniversite öğrencisi üzerinde gerçekleştirdikleri çalışmalarının sonuçlarına göre üniversite öğrencilerinin internet kullanımlarının arttığını ve öğrencilerin yeni teknolojileri takip ettiklerini ortaya koymuşlardır. Aiken vd. (2003), ABD'deki bir üniversitede öğrenim gören öğrencilerin internet kullanımı ile ilgili yaptıkları çalışmalarında elektronik postanın öğrencilerin akademik ve sosyal hayatları için önemli bir faktör olduğunu tespit etmişlerdir. Benzer şekilde Walmsley vd. (2003), İngiltere'de üniversite öğrencileri ve personelinin internet kullanımları ve tutumları ile ilgili bir çalışma yapmışlaradır. Söz konusu çalışmada katılımcıların büyük bir kısmının internet erişimine sahip olduğunu, öğrencilerin ve personelin internet kullanımları arasında farklılıklar olduğunu, hem öğrencilerin hem de personelin interneti okul ve iş yaşamlarında bir kaynak olarak kullandıklarını saptamışlardır. Bazı çalışmalar da ise kullanıcı bakış açısıyla mobil internetin ticaret üzerindeki etkileri incelenmiştir (Chen ve Dubinsky, 2003; Kim ve Chae, 2003: Kim vd., 2007;Gao, CD., 2011). 
Türkiye'de mobil internet ile ilgili yapılan ampirik çalışmalar oldukça sınırlıdır. Bu çalışmalarda mobil internet mobil telefonlar kapsamından incelenmiştir. Bu bağlamda Çakmak ve Yalçın (2013) üniversite öğrencilerinin mobil telefon kullanım özelliklerini betimlemek amacıyla yaptıkları araştırma sonuçlarına göre mobil telefon seçimlerinde performans, kullanım kolaylığ 1 ve tasarım özelliklerinin önemli olduğu tespit edilmiş ve mobil genel ağ kullanımlarında ise e-posta kontrolü ve sosyal ağ takibinin yer aldığı belirtilmiştir. Koç ve Turan (2014) Sakarya Üniversitesi tarafından geliştirilen Sakarya Üniversitesi Mobil Bilgi Sistemi uygulamasının kullanımı ve kabulünün ilişkin olarak yapılan araştırmada kişilerin mobil uygulamayı kullanma niyeti üzerinde kullanım kolaylığı, içerik ve güven faktörlerinin istatistiksel açıdan önemli olduğu ancak; kişisel özellikler ile algılanan fayda değişkenlerinin kullanma niyeti üzerinde istatistiksel olarak anlamlı bir etkisinin olmadığ1 tespit edilmiştir. Durak vd. (2011), üniversite öğrencilerinin internet bağımlılığ1 ve kişilik özelliklerini belirlemek amaciyla Ankara ve İstanbul illerindeki çeşitli özel ve devlet üniversitelerinde öğrenim gören 1198 üniversite öğrencisi üzerinde yaptıkları çalışmada, öğrencilerin internet bağımlısı olduğu ve erkeklerin kadınlara göre daha çok internet bağımlısı olabilecekleri tespit edilmiştir. Uğur ve Turan (2015), üniversite öğrencilerinin mobil uygulamalarının kabulü ve kullanımı ile ilgili yaptıkları çalışmada öğrencilerin büyük çoğunluğunun üniversiteye başladıkları dönemde akıllı telefon aldıkları, erkeklerin mobil uygulamaların benimsenmesi konusunda kadınlara göre daha çekimser oldukları ve akıllı telefon kullanım süresi arttıkça kişilerin mobil uygulama benimseme eğiliminde de artış olduğu tespit edilmiştir.

Türkiye'de Şıklar vd. (2015), üniversite öğrencileri üzerinde mobil internet kullanımının benimsenmesini teknoloji kabul modeli ile araştırmışlardır. Çalışmanın verileri yapısal eşitlik modeli ile analiz edilmiştir. Yapılan analizler sonucunda imaj ve algılanan kullanım kolaylığının algılanan kullanışlılık ile ilişkili olmadığı; bununla beraber yakınsama, algılanan kullanışlılık, kullanım tutumu ve kullanım niyeti arasındaki ilişkilerin anlamlı olduğu tespit edilmiştir. Türkiye' de TAM modeli üzerinde internet kullanımını inceleyen bir başka çalışma Bolat, Aydemir ve Karaman'ın (2017) çalışmasıdır. Söz konusu çalışmada uzaktan eğitim öğrencilerinin öğretimsel etkinliklere mobil ortamda katılmalarına yönelik tutumlarının TAM'a göre incelenmiş ve uzaktan eğitim öğrencilerinin mobil internet kabul ve kullanım düzeylerinin olumlu olduğu bulunmuştur.

Literatür incelendiğinde yaygın bir biçimde internet kullanımının davranışsal özellikleri Davis'in geliştirildiği (1989) Teknoloji Kabul Modeli üzerinden incelenmiştir. Bu model teknoloji ve yenilik davranışları inceleyen bir model olması nedeniyle akademisyenlerin mobil internet kullanım davranış ve tutumları bu model üzerinden incelenmiştir. Çalışmada da eğitim düzeyi yüksek olan bir örneklem üzerinde mobil internet seçiminde etkili olan davranışsal özelikler daha önce geliştirilen Teknoloji Kabul Modeli üzerinde incelenmeye çalışılmıştır.

\section{Materyal ve yöntem}

$\mathrm{Bu}$ araştırma, mevcut durumun değerlendirmesine yönelik kesitsel nitelikte ve analitik bir araştırmadır. Karşılaştırma amacıyla herhangi bir kontrol grubu kullanılmamış; bağımlı ve bağımsız olabilecek değişkenler arasında çoklu ilişkiler aranmıştır. Bağımsız değişkenler; yaş, 
cinsiyet, medeni durum, aylık gelir, toplam çalışma süresi ve akademik başarıdır. Bağımlı Değişkenler; mobil internet tercih alt ölçekleridir.

Araştırmanın evrenini; Bingöl Üniversitesinde çalışan akademisyenlerden oluşturmaktadır. Araştırma grubu Bingöl Üniversitesi Personel Daire Başkanlığından Ekim 2015'te alınan sayılarla belirlenmiştir (Tablo 1). Araştırmada herhangi bir örneklem seçilmemiş, evrenin tümü araştırmanın kapsamına alınmıştır $(\mathrm{N}=491)$. Ancak çalışmanın yapıldı̆̆ı dönemde yeni kurulan Bingöl Üniversitede çalışan akademik personelin büyük bir kısmı araştırma görevlisi ve öğretim görevlisinden oluşmaktaydı. Bu akademik personel lisansüstü eğitimini almak için görevlendirme ile başka ildeki üniversitelere ya da yurt dışına geçiş yapmaktadır. İzinde olan, başka üniversitelerde görevlendirilen ve yurtdışında olan 191 akademisyene anket uygulanamamıştır. Kasım-Aralık 2015 döneminde toplam 300 akademisyene anket uygulanmıştır.

Tablo 1. Akademik Personel Dă̆ılımı

\begin{tabular}{lccc}
\hline Unvan & Bay & Bayan & Toplam \\
\hline Profesör & 22 & - & 22 \\
Doçent & 24 & - & 24 \\
Yardımcı Doçent & 69 & 39 & 108 \\
Öğretim Görevlisi & 67 & 29 & 96 \\
Araştırma Görevlisi & 166 & 54 & 220 \\
Okutman & 17 & 4 & 21 \\
\hline Toplam & 365 & 126 & 491 \\
\hline
\end{tabular}

Araştırma verilerinin toplama yöntemi olarak anket tekniği kullanılmıştır. Anket formu sosyodemografik özellikler ve mobil internet tercih ölçeği olmak üzere iki bölümden oluşmuştur. Sosyodemografik veri toplama formunda akademisyenlerin cinsiyeti, yaşı, medeni durumu, aylık geliri, toplam çalışma süresi ve mobil internetin akademik başarı üzerindeki etkisi ile ilgili çoktan seçmeli ve açık uçlu sorulardan oluşmaktadır.

Araştırmada, Şıklar, Tunalı ve Gülcan (2015) tarafından Davis (1989), Venkatesh ve Davis (2000), Cheng ve diğerlerinin (2006) çalışmalarında kullanılan teknoloji kabul modelindeki algılanan kullanışlılık, algılanan kullanım kolaylığı, kullanım tutumu ve kullanım niyeti alt boyutlarına imaj ve yakınsama boyutları eklenerek geliştirilen teknoloji kabul modeli kullanılmıştır. Toplam 20 maddeden oluşan bu ölçek, maddeleri mobil internet kabulünü ölçen formda puanlar 5'li likert tipinde olup, (1) Hiç katılmıyorum, (2) Az katılıyorum, (3) Orta derecede katıliyorum, (4) Çok katılıyorum, (5) Tam katılıyorum olarak sıralanmıştır. Teknoloji kabul modeli 6 alt ölçekten oluşmaktadır.

Bu ölçek ve anket soru numaraları aşağıdaki gibidir:

1. Faktör: Algılanan Kullanışlılık : 1,2,3

2. Faktör: Algilanan Kullanım Kolaylığı: 4,5,6

3. Faktör: Kulanım Tutumu: $7,8,9,10$

4. Faktör: Kullanım Niyeti: $11,12,13$ 
5. Faktör: İmaj: $14,15,16,17$

6. Faktör: Yakınsama: $18,19,20$

Bu çalışmada kullanılan TAM modeli (Şıklar, vd. 2015) mobil internet tercih ölçeği olarak kabul edilmiş ve yorumlar yapılırken bu isim kullanılmıştır. Çünkü TAM modelindeki değişkenler mobil tercihi ile ilgili olduğu değerlendirilmiştir.

Araştırma sonunda elde edilen veriler bilgisayar ortamında SPSS programı ile bilgisayara girişi yapıldıktan sonra, analizler de bu program aracılığı ile yapılmıştır. Normallik varsayımı, Shapiro Wilk testi ile yapılmıştır. Veriler normal dağılmadığ 1 için analizlerde parametrik olmayan testler tercih edilmiştir. Bu bağlamda analizlerde; betimsel istatistiksel teknikleri, Mann Whitney U testi, Kruskal Wallis varyans, kümeleme ve Spearman's Rank Order korelasyon analizi kullanılmıştır. Çoklu karşılaştırmalar ise Tukey testi ile yapılmıştır. Ortalamalar ( $\bar{X}$ ) standart sapma (S) ile birlikte verilmiş, istatistiksel anlamlılık için $\mathrm{p}<0.05$ değeri alınmıştır.

\section{BULGULAR}

\subsection{Araştırmaya Katılan Hekimlerin Sosyo-Demografik Özelikleri}

Araştırmaya katılan akademisyenlerin yaş ortalaması $33.75 \pm 6.65$ 'dir. Akademisyenlerin $\% 53^{\prime}$ ü 30 39 yaş arasında, \%67.3'ü evli ve \%76'sı erkektir (Tablo 2). Akademisyenlerin toplam hizmet süresine bakıldığında; \%37'si $1-5$ yıl ve \%5.3'ü ise 20 yıl ve üzeri toplam hizmet süresine sahip oldukları saptanmıştır (Tablo 2).

Tablo 2. Hekimlerin Bazı Sosyo-Demografik Özeliklerine Göre Dağılımları.

\begin{tabular}{|c|c|c|c|}
\hline \multicolumn{2}{|c|}{ Sosyo-Demografik Özelik } & \multirow{2}{*}{$\begin{array}{c}\text { Sayı } \\
228\end{array}$} & \multirow{2}{*}{$\begin{array}{c}\mathbf{\%} \\
76.0\end{array}$} \\
\hline Cincivoti & Erkek & & \\
\hline Cinsiyeti & Kadın & 72 & 24.0 \\
\hline \multirow{3}{*}{ Yaş grupları } & 29 ve alt1 & 93 & 31.0 \\
\hline & $30-39$ & 159 & 53.0 \\
\hline & 40 ve üzeri & 48 & 16.0 \\
\hline \multirow{2}{*}{$\begin{array}{l}\text { Medeni } \\
\text { durumu }\end{array}$} & Evli & 202 & 67.3 \\
\hline & Bekar & 98 & 32.7 \\
\hline \multirow{5}{*}{$\begin{array}{l}\text { Toplam } \\
\text { hizmet } \\
\text { süresi }\end{array}$} & $1-5 \mathrm{y} 1 \mathrm{l}$ & 111 & 37.0 \\
\hline & $5-10$ yil & 95 & 31.7 \\
\hline & $10-15$ yıl & 49 & 16.3 \\
\hline & $15-20$ yıl ve üstü & 29 & 9.7 \\
\hline & 20 yıl ve üstü & 16 & 5.3 \\
\hline
\end{tabular}

Akademisyenlerin ortalama aylık geliri $5074.83 \pm 1222.83$ TL olarak bulunmuştur. Araştırma kapsamına alınan akademisyenlerin \%66.7'si mobil internetin akademik başarısını artırdığını, \%33.3'ü ise mobil internetin akademik başarısını artırmadığını beyan etmiştir (Tablo 3). 
Tablo 3. Akademisyenlerin Mobil İnternetin Akademik Başarısını Artırıp Artırmadığı Fikrine Göre Dağılımları

\begin{tabular}{lcc}
\hline & Sayı & $\%$ \\
\hline Evet & 200 & 66.7 \\
Hayır & 100 & 33.3 \\
\hline Toplam & 300 & 100.0 \\
\hline
\end{tabular}

\subsection{Araştırmada Kullanılan Ölçeklerin Puanlarının Değerlendirilmesi}

\subsubsection{Mobil İnternet Tercih Ölçeği Puanının Değerlendirilmesi:}

Anket sorularındaki her yargıya verilen cevapların değerlendirilmesi için aritmetik ortalama kullanılmıştır. Bunun için puan aralığını hesaplamak gerekir. Bu bağlamda aralıkların eşit olduğu varsayımı altında, aritmetik ortalamalar için puan aralığı 0.80 olarak hesaplanmıştır ${ }^{1}$. Buna göre katılımcıların ortalama puanı 1.00-1.80 olan değişkenlere hiç katılmadıkları, ortalama puanı 1.812.60 olan değişkenlere az katıldıkları, ortalama puanı 2.61-3.40 olan değişkenlere orta derecede katıldıkları, ortalama puanı 3.41-4.20 olan değişkenlere çok katıldıkları ve ortalama puanı 4.21-5.00 olan değişkenlere tam katıldıkları gösterdiği kabul edilmiştir.

Çalışmaya katılan akademisyenlerin mobil internet tercihini oluşturan ölçeği oluşturan değişkenlere ilişkin ifadelerin dağılımı Tablo 4 'te yer verilmiştir. Buna göre elde edilen bulgular bir bütün olarak ele alındığında, akademisyenlerin büyük bir çoğunluğunun mobil internet tercihi ilgili değişkenlere çok katıldıkları görülmektedir. Akademisyenlerin mobil internet tercihinde önemli gördükleri faktörlerin önem algılamalarına göre sırasıyla şunlar olduğu görülmektedir: "Mobil internet vasitasıyla sosyal medya (facebook, twitter, vb.) yakından takip edilebilir", "Mobil internet ile e- postalar istenilen yerde ve zamanda kontrol edilir", "Mobil internet kullanma iyi bir fikir.", "Mobil internet kullanmayı öğrenmek kolaydır", "Mobil kullanmada kendimi becerikli buluyorum", "Mobil internet üzerinde - dergi, e - kitap ve - gazete okunabilir".

Tablo 4. Akademisyenlerin Mobil İnternet Tercih İle İlgili Algıları

\footnotetext{
${ }^{1}$ Puan Aralığ $1=($ En Yüksek Değer - En Düşük Değer $) / 5=(5-1) / 5=4 / 5=0.80$
} 


\begin{tabular}{|c|c|c|c|c|c|c|c|}
\hline Mobil İnternet Tercih Değişkenleri & 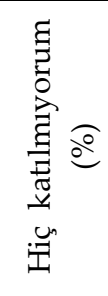 & 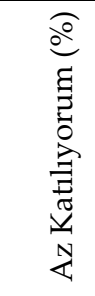 & 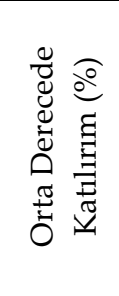 & 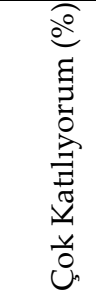 & 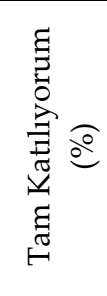 & $\bar{X}$ & S \\
\hline $\begin{array}{l}\text { Mobil internet kullanımı internette daha hızlı işlem yapmasını } \\
\text { sağlar. }\end{array}$ & 6.0 & 10.3 & 9.0 & 37.7 & 37.0 & 3.89 & 1.19 \\
\hline $\begin{array}{l}\text { Mobil internet kullanımı internetteki işlemleri daha pratik hale } \\
\text { getirir. }\end{array}$ & 4.3 & 7.3 & 7.7 & 44.0 & 36.7 & 4.01 & 1.06 \\
\hline Mobil İnternet kullanımı internetteki işlemlerim için kullanışlıdır. & 3.7 & 9.3 & 7.0 & 47.3 & 32.7 & 3.96 & 1.05 \\
\hline Mobil internet kullanımı benim için kolaydır. & 3.3 & 8.7 & 5.7 & 43.3 & 39.0 & 4.06 & 1.06 \\
\hline Mobil internet kullanmayı öğrenmek kolaydır. & 2.7 & 3.7 & 9.7 & 51.7 & 32.3 & 4.07 & 0.90 \\
\hline Mobil kullanmada kendimi becerikli buluyorum. & 1.7 & 8.0 & 10.7 & 44.3 & 35.3 & 4.04 & 0.97 \\
\hline Mobil internet kullanma iyi bir fikir. & 3.3 & 6.0 & 7.3 & 44.7 & 38.7 & 4.09 & 1.00 \\
\hline Mobil internet kullanmada kendimi keyif alıyorum. & 3.0 & 13.7 & 10.7 & 40.3 & 32.3 & 3.85 & 1.11 \\
\hline Mobil internet kullanmak istenilen bir durumdur. & 1.3 & 9.7 & 16.0 & 46.3 & 26.7 & 3.87 & 0.96 \\
\hline Mobil internet kullanma akıllıca bir fikir. & 5.7 & 8.7 & 12.0 & 46.7 & 27.0 & 3.81 & 1.10 \\
\hline İnternet ihtiyacım olduğunda mobil internet kullanmıyorum. & 34.0 & 36.3 & 7.7 & 14.0 & 8.0 & 2.26 & 1.28 \\
\hline $\begin{array}{l}\text { Gelecekte mobil internet erişime sahip olduğunda bunu } \\
\text { kullanacağımı tahmin ediyorum. }\end{array}$ & 5.0 & 6.0 & 16.0 & 48.3 & 24.7 & 3.82 & 1.03 \\
\hline Gelecekte mobil internet kullanmayı sürdüreceğim. & 6.0 & 5.3 & 9.7 & 45.7 & 33.3 & 3.95 & 1.09 \\
\hline $\begin{array}{l}\text { Mobil internet sayesinde sesli ve görüntülü görüşme yapmak } \\
\text { önemdir. }\end{array}$ & 4.3 & 8.0 & 12.3 & 43.7 & 31.7 & 3.90 & 1.08 \\
\hline Mobil internet üzerinde - dergi, e - kitap ve - gazete okunabilir. & 3.7 & 6.3 & 6.3 & 49.7 & 34.0 & 4.04 & 0.99 \\
\hline $\begin{array}{l}\text { Mobil internet vasitasiyla sosyal medya(facebook, twitter, vb.) } \\
\text { yakından takip edilebilir. }\end{array}$ & 3.0 & 4.3 & 5.7 & 44.3 & 42.7 & 4.19 & 0.94 \\
\hline $\begin{array}{l}\text { Mobil internet ile e- postalar istenilen yerde ve zamanda kontrol } \\
\text { edilir. }\end{array}$ & 5.7 & 3.0 & 7.7 & 36.0 & 47.7 & 4.17 & 1.08 \\
\hline $\begin{array}{l}\text { Mobil internet kullananlar, kullanmayanlardan daha fazla } \\
\text { prestije sahiptir. }\end{array}$ & 25.0 & 24.7 & 26.3 & 16.0 & 8.0 & 2.57 & 1.25 \\
\hline Mobil internet kullananlar üst düzey kişilerdir. & 37.0 & 31.0 & 20.0 & 7.3 & 4.7 & 2.12 & 1.13 \\
\hline Mobil internet kullanmak bir statü sembolüdür & 35.7 & 32.0 & 16.0 & 9.0 & 7.3 & 2.20 & 1.22 \\
\hline
\end{tabular}

\subsubsection{Mobil İnternet Tercih Ölçeğinin Alt Ölçek Puanlarının Değerlendirilmesi:}

Mobil internet tercih alt ölçeklerinin ortalama puanları incelendiğinde; algılanan kullanışlılık alt ölçeğinin ortalama puanı $3.96 \pm 1.00$, algılanan kullanım kolaylığı alt ölçeğinin ortalama puanı 4.06 \pm 0.87 , kullanım tutumu alt ölçeğinin ortalama puanı $3.91 \pm 0.87$, kullanım niyeti alt ölçeğinin ortalama puanı $3.34 \pm 0.68$, yakınsama alt ölçeğinin ortalama puanı $4.08 \pm 0.83$ ve imaj alt ölçeği ortalama puanı $2.30 \pm 1.03$ olarak bulunmuştur (Tablo 5). 
Tablo 5. Akademisyenlerin Mobil İnternet Tercih Alt Ölçeklerinin Ortalama Puanlarının Dağılımı $(\mathrm{n}=300)$

\begin{tabular}{lccc}
\hline $\begin{array}{l}\text { Mobil İnternet Tercih Alt } \\
\text { Ölçekleri }\end{array}$ & $\begin{array}{c}\text { Madde } \\
\text { Sayısı }\end{array}$ & $\bar{X}$ & S \\
\hline Algılanan Kullanışlılık & 3 & 3.96 & 1.00 \\
Algılanan Kullanım Kolaylı̆̆ı & 3 & 4.06 & 0.87 \\
Kullanım Tutumu & 4 & 3.91 & 0.87 \\
Kullanım Niyeti & 3 & 3.34 & 0.68 \\
Yakınsama & 4 & 4.08 & 0.83 \\
İmaj & 3 & 2.30 & 1.03 \\
\hline
\end{tabular}

\subsection{Araştırmada Kullanılan Ölçeklerin Demografik Değişkenlerle İlişkisinin Değerlendirilmesi}

Araştırmaya katılan akademisyenlerin cinsiyete göre mobil internet tercih alt boyutunun ortalama puanı değişimi Tablo 6'da verilmiştir. Buna göre algılanan kullanışlılık boyutu ile cinsiyet arasında anlamlı bir ilişki bulunmaktadır. Kadın ile erkek akademisyenler arasında istatiksel olarak algılanan kullanışlılık boyutunda anlamlı bir farklılık bulunmaktadır ( $\mathrm{p}=0.035)$.

Tablo 6. Akademisyenlerin Cinsiyetlerine Göre Mobil İnternet Tercih Alt Ölçeklerinin Ortalama Puanlarının Dağılımı

\begin{tabular}{llll}
\hline Değişken & Kadın & Erkek & P değeri* $^{*}$ \\
\hline Algılanan Kullanışlılık & $4.00[(1.67)-(5.00)]$ & $4.00[(1.00)(5.00)]$ & $\mathbf{0 . 0 3 1}$ \\
Algılanan Kullanım Kolaylığı & $4.17[(2.00)-(5.00)]$ & $4.00[(1.00)(5.00)]$ & 0.161 \\
Kullanım Tutumu & $4.00[(2.00)-(5.00)]$ & $4.00[(1.00)(5.00)]$ & 0.157 \\
Kullanım Niyeti & $3.33[(1.67)-(4.67)]$ & $3.33[(1.00)(5.00)]$ & 0.856 \\
Yakınsama & $4.25[(2.00)-(5.00)]$ & $4.00[(1.00)(5.00)]$ & 0.212 \\
İmaj & $2.00[(1.00)-(4.00)]$ & $2.33[(1.00)(5.00)]$ & 0.096 \\
\hline
\end{tabular}

*Mann Whitney U testi, -Değerler ortanca [min, max] olarak verildi,

Araştırmaya katılan akademisyenlerin medeni durumlarına göre mobil internet tercih alt boyutunun ortalama puanları Tablo 7'de verilmiştir. Medeni durma göre mobil internet tercih alt boyutlarının otalama pumaları farklı değildir $(\mathrm{p}>0.05)$.

Tablo 7. Akademisyenlerin Medeni Durumlarına Göre Mobil İnternet Tercih Alt Ölçeklerinin Ortalama Puanlarının Dağılımı

\begin{tabular}{lccccc}
\hline Mobil İnternet Tercih Alt & \multicolumn{2}{c}{ Evli } & \multicolumn{2}{c}{ Bekâr } & \multirow{2}{*}{ P } \\
\cline { 2 - 5 } Ölçekleri & $\bar{X}$ & $\mathbf{S}$ & $\bar{X}$ & $\mathbf{S}$ & 0.337 \\
\hline Algılanan Kullanışlılık & 3.95 & 0.96 & 3.98 & 1.06 & 0.904 \\
Algılanan Kullanım Kolaylı̆̆1 & 4.09 & 0.76 & 3.98 & 3.71 & 0.489 \\
Kullanım Tutumu & 3.91 & 0.81 & 3.91 & 0.99 & 0.950 \\
Kullanım Niyeti & 3.34 & 0.72 & 3.35 & 0.60 & 0.883 \\
Yakınsama & 4.08 & 0.79 & 4.07 & 0.91 & 0.064 \\
İmaj & 2.37 & 1.04 & 2.14 & 0.99 & \\
\hline
\end{tabular}

Araştırmaya katılan akademisyenlerin yaş gruplarına göre mobil internet tercih alt ölçeklerinin 
ortalama puanları Tablo 8'de verilmiştir. Yapılan analiz sonucuna göre \%5 anlamlılık düzeyine göre kullanım niyeti ile yakınsama alt boyutları hariç tüm alt boyutların ortalama puanları ile akademisyenlerin yaş grupları arasında istatiksel olarak anlamlı bir farklılık olduğu saptanmıştır. Yaş gruplarına göre akademisyenlerin algılanan kullanışlılık alt ölçeği puan ortalaması arasındaki farklılığın hangi gruplar arasında olduğunu bulmak için yapılan çoklu karşılaştırma analizi sonucuna göre 40 ve üzeri yaş grubu ile 29 ve altı yaş grubunda bulunan akademisyenlerin $(\mathrm{p}=0.015)$ ölçek puanları arasında anlamlı farklılık bulunmuştur. Buna göre genç akademisyenler yaşlı akademisyenler ile kıyaslandığında anlamlı olarak mobil tercihinde daha fazla algılanan kullanışlılığa önem vermektedirler. Benzer bir biçimde algılanan kullanım kolaylığı alt ölçeği puan ortalaması arasındaki farklılığın hangi gruplar arasında olduğunu bulmak için yapılan çoklu karşılaştırma analizi sonucuna göre 40 ve üzeri yaş grubu ile 29 ve altı yaş 40 ve üzeri yaş grubu ile 30-39 yaş grubunda bulunan akademisyenlerin $(\mathrm{p}=0.000)$ ölçek puanları arasında anlamlı farklılık bulunmuştur.

Tablo 8. Akademisyenlerin Yaş Gruplarına Göre Mobil İnternet Tercih Alt Ölçeklerinin Ortalama Puanlarının Dağılımı

\begin{tabular}{lccccccc}
\hline Mobil İnternet & \multicolumn{2}{c}{ 29 ve altı yaş } & \multicolumn{2}{c}{ 30-39 yaş } & \multicolumn{2}{c}{ 40 ve üzeri yaş } & \multirow{2}{*}{ P } \\
\cline { 2 - 7 } Tercih Alt Ölçekleri & $\bar{X}$ & $\mathbf{S}$ & $\bar{X}$ & $\mathbf{S}$ & $\bar{X}$ & $\mathbf{S}$ & \\
\hline Algılanan Kullanışlılık & $4.11^{\mathrm{b}}$ & 0.97 & 3.95 & 1.05 & $3.69^{\mathrm{a}}$ & 0.88 & $\mathbf{0 . 0 1 9}$ \\
Algılanan Kullanım & & & & & & & \\
Kolaylı̆̆ & $4.13^{\mathrm{a}}$ & 0.88 & $4.13^{\mathrm{b}}$ & 0.86 & $3.66^{\mathrm{b}}$ & 0.77 & $\mathbf{0 . 0 0 0}$ \\
Kullanım Tutumu & $4.02^{\mathrm{a}}$ & 0.90 & 3.91 & 0.87 & $3.68^{\mathrm{b}}$ & 0.79 & $\mathbf{0 . 0 1 8}$ \\
Kullanım Niyeti & 3.41 & 0.63 & 3.31 & 0.66 & 3.32 & 0.83 & 0.612 \\
Yakınsama & 4.16 & 0.81 & 4.08 & 0.86 & 3.91 & 0.76 & 0.087 \\
İmaj & $2.15^{\mathrm{a}}$ & 0.97 & $2.26^{\mathrm{b}}$ & 1.04 & $2.69 \mathrm{~b}$ & 1.04 & $\mathbf{0 . 0 0 8}$ \\
\hline
\end{tabular}

a,b: Aynı satırda farklı harfleri içeren grup ortalamaları arası farklar önemlidir $(\mathrm{p}<0.05)$.

Çalışmadaki veriler göz önüne alınarak akademisyenler aylık gelir düzeylerine göre üç kümeye (Cluster) ayrılmıştır. Birinci grubu (C1) oluşturan akademisyenler düşük gelir (aylık ortalama 2768, 35TL), İkinci grubu (C2) oluşturan müşteriler orta gelir (aylık ortalama 4963,97 TL) ve son olarak da üçüncü grubu (C3) oluşturan müşteriler ise yüksek gelir (aylık ortalama 7215,56) düzeyine sahip akademisyenler olarak tanımlanmış ve sinıflandırılmışlardır. Birinci grupta (C1) 31, İkinci grupta (C2) 224 ve son olarak da üçüncü grupta (C3) 45 adet akademisyen bulunmaktadır. Buna göre anket yapılan akademisyenlerin \%74.66'si orta gelir düzeyi grubunda, \%15'i yüksek gelir düzeyi grubunda ve \%10,33’ü ise düşük gelir düzeyi grubunda yer almışlardır.

Çalışmada yapılan analizde \%5 anlamlılık düzeyine göre akademisyenlerin gelir düzeyleri arasında algılanan kullanışlılık ve imaj ölçek ortalama puanlarının istatiksel olarak anlamlı bir şekilde farklı olduğu söylenilebilir $(\mathrm{p}<0.05)$. Yani akademisyenlerin gelir düzeylerinin algılanan kullanışlılık ve imaj ölçek puan dağılımları arasında önemli farklılık vardır. Bu farklılı̆̆ın hangi gelir düzeyleri arasında olduğunu bulmak için yapılan çoklu karşılaştırma testi sonucunda yüksek ve orta gelir düzeyine sahip olan akademisyenlerde algılanan kullanışlılık ölçek puanları farklı $(\mathrm{p}=0.028)$ olduğu saptanmıştır (Tablo 9). 
Tablo 9. Akademisyenlerin Gelir Gruplarına Göre Mobil İnternet Tercih Alt Ölçeklerinin Ortalama Puanlarının Dağılımı

\begin{tabular}{lccccccc}
\hline $\begin{array}{l}\text { Mobil İnternet } \\
\begin{array}{l}\text { Tercih Alt } \\
\text { Ölçekleri }\end{array}\end{array}$ & $\overline{\boldsymbol{X}}$ & $\boldsymbol{S}$ & $\overline{\boldsymbol{X}}$ & $\boldsymbol{S}$ & $\overline{\boldsymbol{X}}$ & $\boldsymbol{S}$ & P değeri* $^{*}$ \\
\cline { 2 - 7 } $\begin{array}{l}\text { Algılanan } \\
\text { Kullanışlılık }\end{array}$ & 4.04 & 1.10 & $4.02^{\mathrm{b}}$ & 0.98 & $3.60^{\mathrm{a}}$ & 1.03 & $\mathbf{0 . 0 2 4}$ \\
$\begin{array}{l}\text { Algılanan Kullanım } \\
\text { Kolaylığı }\end{array}$ & 4.24 & 0.78 & 4.06 & 0.89 & 3.93 & 0.79 & 0.142 \\
Kullanım Tutumu & 3.98 & 0.96 & 3.94 & 0.87 & 3.68 & 0.80 & 0.059 \\
Kullanım Niyeti & 3.29 & 0.64 & 3.33 & 0.70 & 3.43 & 0.62 & 0.749 \\
Yakınsama & 4.10 & 0.73 & 4.11 & 0.83 & 3.87 & 0.86 & 0.109 \\
İmaj & 2.49 & 0.93 & 2.21 & 1.01 & 2.58 & 1.07 & $\mathbf{0 . 0 4 0}$ \\
\hline
\end{tabular}

${ }^{*}$ Kruskal-Wallis Test

Araştırmaya katılan akademisyenlerin toplam hizmet süresine göre mobil internet tercih alt boyutunun ortalama puanı değişimi Tablo 10'da sunulmuştur. Buna göre algılanan kullanım, kullanım tutumu ve kullanım niyeti alt boyları ile mesleki deneyimi arasında anlamlı bir ilişki bulunmaktadır $(\mathrm{p}<0.05)$.

Tablo 10. Akademisyenlerin Toplam Hizmet Süresine Göre Mobil İnternet Tercih Alt Ölçeklerinin Ortalama Puanlarının Dağ 1 lımı

\begin{tabular}{|c|c|c|c|c|c|c|}
\hline \multirow{2}{*}{$\begin{array}{l}\text { Mobil İnternet } \\
\text { Tercih Alt } \\
\text { Ölçekleri }\end{array}$} & $1-5$ y1l & $5-10$ yıl & 10-15 y1l & $15-20$ y1l & $\begin{array}{l}20 \text { yıl ve } \\
\text { üzeri }\end{array}$ & \multirow[t]{2}{*}{$\mathbf{P}$} \\
\hline & $\bar{X} \pm \mathrm{S}$ & $\bar{X} \pm \mathrm{S}$ & $\bar{X} \pm \mathrm{S}$ & $\bar{X} \pm \mathrm{S}$ & $\bar{X} \pm \mathrm{S}$ & \\
\hline $\begin{array}{l}\text { Algilanan } \\
\text { Kullanışlılık }\end{array}$ & $4.10 \pm 0.96$ & $3.87 \pm 1.07$ & $3.97 \pm 1.07$ & $3.90 \pm 0.71$ & $3.50 \pm 1.03$ & 0.093 \\
\hline $\begin{array}{l}\text { Algılanan } \\
\text { Kullanım } \\
\text { Kolaylı̆̆ı }\end{array}$ & $4.15 \pm 0.87^{\mathrm{b}}$ & $4.08 \pm 0.91^{\mathrm{b}}$ & $4.12 \pm 0.92^{b}$ & $3.82 \pm 0.64$ & $3.48 \pm 0.62^{\mathrm{a}}$ & 0.000 \\
\hline $\begin{array}{l}\text { Kullanım } \\
\text { Tutumu }\end{array}$ & $4.06 \pm 086^{b}$ & $3.90 \pm 0.91$ & $3.88 \pm 10.82$ & $3.57 \pm 0.77^{\mathrm{a}}$ & $3.63 \pm 0.89$ & 0.016 \\
\hline Kullanım Niyeti & $3.40 \pm 0.62^{b}$ & $3.35 \pm 0.59^{b}$ & $3.45 \pm 0.56^{\mathrm{b}}$ & $2.79 \pm 1.05^{\mathrm{a}}$ & $3.54 \pm 0.68^{b}$ & 0.007 \\
\hline Yakınsama & $4.15 \pm 0.85^{\mathrm{a}}$ & $4.11 \pm 0.85^{\mathrm{b}}$ & $3.91 \pm 0.95^{b}$ & $3.95 \pm 0.59^{\mathrm{a}}$ & $4.09 \pm 0.55$ & 0.174 \\
\hline İmaj & $2.15 \pm 0.91$ & $2.27 \pm 1.06$ & $2.34 \pm 1.17$ & $2.62 \pm 0.98$ & $2.77 \pm 1.16$ & 0.076 \\
\hline
\end{tabular}

Araştırmaya kapsamına alınan akademisyenlerin mobil internetin akademik başarısını artırıp artırmamasına göre mobil internet tercih alt boyutunun ortalama puanı değişimi Tablo 11'de sunulmuştur. Buna göre algılanan kullanışlılık, algılanan kullanım ve kullanım tutumu boyutları ile akademik başarı arasında önemli derecede $(\mathrm{p}<0.01)$ anlamlı bir ilişki bulunmaktadır. Yani anlamlı olarak mobil internetin akademik başarıyı artırdı̆̆ına inan akademisyenlerin algılanan kullanışlılık, algılanan kullanım ve kullanım tutumu boyutlarının ortalama puanları daha yüksek olduğu tespit edilmiştir.

Tablo 11. Mobil internetin akademik başarı üzerindeki etkisine Göre Mobil İnternet Tercih Alt Ölçeklerinin Ortalama Puanlarının Dağılımı 


\begin{tabular}{lccc}
\hline $\begin{array}{l}\text { Mobil İnternet Tercih Alt } \\
\text { Ölçekleri }\end{array}$ & Evet & Hayır & P değeri $^{*}$ \\
\hline Algılanan Kullanışlılık & $4.00[(1.00)-(5.00)]$ & $4.00[(1.00)(5.00)]$ & $\mathbf{0 . 0 0 0}$ \\
Algılanan Kullanım Kolaylığı & $4.33[(2.00)-(5.00)]$ & $4.00[(1.00)(5.00)]$ & $\mathbf{0 . 0 0 1}$ \\
Kullanım Tutumu & $4.00[(2.00)-(5.00)]$ & $4.00[(1.00)(5.00)]$ & $\mathbf{0 . 0 0 0}$ \\
Kullanım Niyeti & $3.33[(1.67)-(4.67)]$ & $3.33[(1.00)(5.00)]$ & 0.461 \\
Yakınsama & $4.25[(2.00)-(5.00)]$ & $4.00[(1.00)(5.00)]$ & 0.056 \\
İmaj & $2.00[(1.00)-(4.00)]$ & $2.33[(1.00)(5.00)]$ & 0.994 \\
\hline
\end{tabular}

${ }^{*}$ Mann Whitney U testi, -Değerler ortanca [min, max] olarak verilmiştir.

Mobil internet tercih alt ölçekleri arasındaki korelasyon Tablo 4'te verilmiştir. Algılanan kullanım kolaylığı ortalama puanı ile algılanan kullanışlılık, kullanım tutumu ve yakınsama ortalama puanları arasında kuvvetli ve pozitif yönlü bir ilişki olduğu bulunmuştur (Tablo 12). İmaj alt boyutunun ortalama puanları ile diğer alt boyutlarının ortalama puanları arasında zayıf ve negatif bir ilişki saptanmıştır.

Tablo 12. Mobil İnternet Tercih Alt Ölçekleri Arasındaki Korelasyon

\begin{tabular}{lcccccc}
\hline $\begin{array}{l}\text { Mobil İnternet Tercih Alt } \\
\text { Ölçekleri }\end{array}$ & $\begin{array}{l}\text { Algılanan } \\
\text { Kullanışlılık }\end{array}$ & $\begin{array}{l}\text { Algılanan } \\
\text { Kullanım } \\
\text { Kolaylığı }\end{array}$ & $\begin{array}{l}\text { Kullanım } \\
\text { Tutumu }\end{array}$ & $\begin{array}{l}\text { Kullanım } \\
\text { Niyeti }\end{array}$ & Yakınsama & İmaj \\
\hline Algılanan Kullanışlılık & 1 & & & & & \\
Algılanan Kullanım Kolaylığı & $0.743^{*}$ & 1 & & & & \\
Kullanım Tutumu & $0.621^{*}$ & $0.654^{*}$ & 1 & & & \\
Kullanım Niyeti & $0.285^{*}$ & $0.244^{*}$ & $0.316^{*}$ & 1 & & \\
Yakınsama & $0.464^{*}$ & $0.519^{*}$ & $0.545^{*}$ & $0.341^{*}$ & 1 & \\
İmaj & $-0.204^{*}$ & $-0.255^{*}$ & $-0.303^{*}$ & 0.096 & $-0.145^{* *}$ & 1 \\
\hline
\end{tabular}

${ }^{*} \mathrm{p}<0.001, \mathrm{p}<0.05$, Not: Nonparematik Spearman'nın rho korelasyon katsayısı kullanılmıştır.

\section{Tartışma ve Sonuç}

Akademisyenler mobil internet tercih alt ölçeklerinde "yakınsama", ölçeğinin ortalama puanı en yüksek olduğu tespit edilmiştir. Daha sonra sırasıyla "algılanan kullanım kolaylı̆̆ı", "algılanan kullanışlılık", "kullanım tutumu" ve "kullanım niyeti" alt ölçeği gelir. Akademisyenlerin mobil internet tercihine en az katkıya sahip alt ölçek "kullanım niyeti" ve "İmaj" alt ölçekleri olduğu saptanmıştır. Bolat ve vd. (2017) öğrenciler üzerinde yaptıkları araştırmada da öğrencilerin mobil internetin benimsenmesinde en çok katkıya sahip alt ölçeğin yakınsama, en az katkıya sahip alt ölçeği ise imaj olduğu belirlenmiştir. Bu bulgu araştırmayı destekler niteliktedir. Yakınsama farklı teknolojik alt yapılara sahip ürünlerin sahip oldukları farklı fonksiyonların aynı ortamda bir araya getirilmesi olarak tanımlanmaktadır (Şıklar vd. , 2015:104). Çalışmaya katılan akademisyenler mobil internettin sahip olduğu ve bir arada sunduğu fonksiyonları mobil internet seçiminde önem verdikleri ifade dilebilir. Bu fonksiyonlar sesli ve görüntülü görüşme, e-dergi, e-kitap ve e-gazete okuma, sosyal medyayı (facebook, twitter, vb.) yakından takip edebilme ve e-postaların istenilen yerde ve zamanda kontrol edilebilmedir. İmaj alt boyutunun tüm alt boyutlar içinde en düşük 
ortalamaya sahip olması akademisyenlerin mobil internettin kişide bir imaj oluşturduğu algısına pek katılmadıklarını göstermektedir.

Akademisyenlerin mobil internet kullanımı ve demografik faktörlere arasındaki ilişki de araştırılmıştır. Erkek akademisyenlerin algılanan kullanışlılık alt ölçeğinin puan ortalaması, kadın akademisyenlerin algılanan kullanışlılık alt ölçeğinin puan ortalamasından anlamlı bir şekilde yüksek bulunmuştur. Algılanan kullanışlılık ölçeği dışındaki diğer mobil internet tercih alt ölçeklerinin puan ortalamaları ile cinsiyet arasında anlamlı bir ilişki bulunmadığı saptanmıştır. Cinsiyetin mobil internet tercihini etkilediği konusunda farklı görüşler vardır. Mobil internet kullanımını etkileyen faktörleri ölçmek için yapılan bazı araştırmalarda mobil internet kullanımı ile cinsiyet arasında ilişki olmadığ1 saptanmıştır (Antoun, 2015; Chatterjee, 2017; Bolat ve vd. 2017). Buna karşılık Ramirez-Correa vd. (2015) tarafından yapılan ampirik çalışmada, cinsiyetin akıllı telefon işletim sistemi ile mobil internet kullanımının davranışsal boyutu arasındaki ilişkide anlamlı olarak önemli rol oynadığı ve işletim sistemleri iOS (iPhone) olan erkeklerin anlamlı olarak daha fazla mobil internet kullanıcısı oldukları saptanmıştır. Bu bulgu araştırmayı destekler niteliktedir.

Araştırmada medeni durum ile mobil internet tercih alt ölçeklerinin puan ortalaması arasında anlamlı bir ilişki bulunmadığı saptanmıştır. Antoun (2015) ve Chatterjee, (2017) yaptıkları araştırmalarda da medeni durum ile mobil internet kullanımı arasında istatiksel açıdan anlamlı bir ilişki tespit edilemediği bildirmişlerdir. Bu sonuçlar araştırma bulgularını destekler niteliktedir.

Yapılan istatistiksel analiz sonucunda kullanım niyeti ile yakınsama alt boyutları hariç tüm alt boyutların ortalama puanları ile akademisyenlerin yaş grupları arasında istatiksel olarak anlamlı bir farklılık olduğu saptanmıştır. Algılanan kullanışlılık ölçeği puan ortalaması ile yaş grupları arasında fark önemli bulunmuştur. Bu farklık ise 40 ve üzeri ile 29 ve altı yaş grupları arasında olduğu saptanmıştır. Buna göre, genç akademisyenler yaşlı akademisyenler ile kıyaslandığında anlamlı olarak mobil internet tercihinde daha fazla algılanan kullanışlılı̆ga önem vermektedirler. Yani genç akademisyenler yaşlı akademisyenlere göre mobil internetin daha pratik olmasına, daha hızlı olmasına ve işlemler için kullanışlı olmasına öneme vermektedir. Algılanan kullanım kolaylığı ölçeğinin puan ortalaması ile yaş grupları arasında fark önemli bulunmuştur. 29 yaş ve altı grubunda bulunan akademisyenlerin algılanan kullanım kolaylığı ölçeğinin puan ortalaması, 30-39 yaş grubu ile 40 ve üzeri yaş grubunda bulunan akademisyenlerin algılanan kullanım kolaylığı ölçeğinin puan ortalamasından anlamlı bir şekilde yüksek bulunmuştur. İmaj ölçeği puan ortalaması ile yaş grupları arasında da fark önemli bulunmuştur. 29 yaş ve altı grubunda bulunan akademisyenlerin imaj ölçeğinin puan ortalaması, 30-39 yaş grubu ile 40 ve üzeri yaş grubunda bulunan akademisyenlerin imaj ölçeğinin puan ortalamasından anlamlı bir şekilde düşük bulunmuştur. Bu sonuç genç akademisyenler yaşlı akademisyenler ile kıyaslandığında mobil internetin kendileri için bir imaj oluşturduğu algısına daha az önem verdiklerini göstermektedir. Yapılan bazı çalışmalarda da genç bireylerin mobil internet kullanıcısı olma olasılıklarının daha yüksek olduğunu bildirilmiştir (Antoun, 2015; Torsten vd. 2016). Ratchford vd. (2013) tarafından tüketicinin internetteki otomobil ile ilgili bilgi ararken kararlarını etkileyen faktörleri belirlemek için yapılan çalışmada yaş, gelir ve eğitim gibi tüketici özelliklerinin çevrimiçi ve çevrimdışı kanallarda arama kriterlerini anlamlı olarak etkilediğini saptamışlardır. Bu bulgu araştırmanın bulguları ile uyumludur. 
Yapılan istatistiksel analiz sonucunda algılanan kullanışlılık ve imaj alt boyutları hariç tüm alt boyutların ortalama puanları ile akademisyenlerin gelir grupları arasında istatiksel olarak anlamlı bir farklılık olmadığı bulunmuştur. Algılanan kullanışlılık ölçeği puan ortalaması ile gelir grupları arasındaki fark ise önemli bulunmuştur. Bu farklık ise yüksek ve orta gelir grupları arasında olduğu saptanmıştır. Orta gelir grubunda bulunan akademisyenler yüksek gelir grubunda bulunan akademisyenler ile karşılaştırıldığında mobil internettin seçiminde algılanan kullanışlılık boyutuna daha fazla önem vermektedir.

Araştırmada algılanan kullanım kolaylı̆̆ı, kullanım tutumu ve kullanım niyeti alt boyları ile mesleki deneyim arasında anlamlı bir ilişki bulunmuştur. Mesleki deneyim ile algılanan kullanım kolaylığı alt ölçeğinin puan ortalaması arasında anlamlı bir ilişki olduğu bulunmuş ve hizmet süresi 20 yıl ve üzeri olan akademisyenlerin algılanan kullanım kolaylığı ölçeğinin ortalama puanı hizmet süresi 1-5 yıl, 5-10 yıl ve 10-15 yıl olan akademisyenlerde anlamlı olarak daha düşük bulunmuştur. Bu bulgu mesleki deneyimi fazla olan akademisyenlerin mobil internetin algılanan kullanım kolaylığına daha az önem verdiklerini göstermektedir. Bunun nedeni mesleki deneyimin kişilerin uzmanlaşmasını sağlaması ve kişilerin yeni teknolojilere kolay bir biçimde adapte olmasını hızlandırmasıdır. Kullanım tutumu ölçeği puan ortalaması ile mesleki deneyim arasında da fark önemli bulunmuştur. 1-5 yıllık mesleki bulunan akademisyenlerin kullanım tutumu ölçeğinin puan ortalaması, 15-20 yıllık mesleki deneyime sahip akademisyenlerin kullanım tutumu ölçeğinin puan ortalamasından anlamlı bir şekilde daha yüksek bulunmuştur. Genel olarak mesleğe yeni başlayan akademisyenler daha genç ve kendilerini geliştirmeye daha istekli bir konumdadır. Dolayısıyla mobil internettin kullanımına daha fazla önem vermektedir.

Çalışmada algılanan kullanışlılık, algılanan kullanım kolaylığı ve kullanım tutumu boyutları ile akademik başarı arasında anlamlı bir ilişki bulunduğu tespit edilmiştir. Yani anlamlı olarak mobil internetin akademik başarıyı artırdığına inan akademisyenlerin algılanan kullanışlılık, algılanan kullanım ve kullanım tutumu boyutlarının ortalama puanları daha yüksek olduğu tespit edilmiştir. $\mathrm{Bu}$ üç boyutta verilen değişkenlerin akademisyenlerin akademik başarısı üzerinde olumlu etki oluşturduğu ifade edilebilir. Bu nedenle mobil internet sağlayıcılarının akademisyenlere yönelik olarak akademik etkinliklerin mobil ortamda yapmaları için mobil platformalar oluşturabilirler. Böylece akademisyenlerin şuanda ve gelecekte mobil internet seçimini olumlu etkilenmiş olur.

Çalışmanın diğer önemli sonucu mobil internet tercih alt ölçeklerinin kendi arlarındaki ilişkileridir. Algılanan kullanım kolaylığı ölçeği ile algılanan kullanışlılık, kullanım tutumu ve yakınsama ölçekleri arasında kuvvetli ve pozitif yönlü bir ilişki olduğu bulunmuştur. İmaj alt ölçeği ile diğer alt ölçekler arasında zayıf ve negatif bir ilişki saptanmıştır. Mobil internet kullanımı daha kolay hale getirilirse, akademisyenlerde mobil internet kullanım tutumu, kullanışlılık algısı ve mobil internetin sahip olduğu fonksiyonların kullanma istekliliği artacaktır. Bu anlamda mobil internet hizmetini sunan firmalar mobil internettin kullanımı daha kolay hale getirmek için daha fazla yatırım yapmaları önerilmemektedir.

Sonuç olarak; tüm akademisyenlerin en az puan ortalamasına sahip oldukları mobil internet tercih alt ölçeği imaj ve kullanım niyetidir. Bu sonuç mobil internet kullanımının akademisyenlerde bir 
imaj oluşturma algısını sağlamadığını göstermektedir. En düşük ortalamaya sahip boyutlardaki değişkenlerin iyileştirmesi mobil internet seçimini olumlu etkileyebilir. Ayrıca mobil internet tercihinin yaş, cinsiyet, gelir, mesleki deneyim ve akademik başarı üzerindeki olumlu etkisine göre tercih edildiği tespit edilmiştir. Mobil internet sağlayıcılarının bu faktörleri ve davranışsal faktörleri dikkatte alarak mobil internet fonksiyonlarını tasarlamaları ve geliştirmeleri önerilmektedir.

\section{Kaynaklar}

Aiken, M., Vanjani, M., Ray, B., Martin, J. (2003). College Student Internet Usage", Campus-Wide Information Systems. 20 (5), 182-185.

Antoun, C. (2015). Who Are the Internet Users, Mobile Internet Users, and Mobile-Mostly Internet Users?: Demographic Differences across Internet-Use Subgroups in the U.S.. In: Toninelli, D, Pinter, R \& de Pedraza, P (eds.) Mobile Research Methods: Opportunities and Challenges of Mobile Research Methodologies, pp. 99-117. London: Ubiquity Press. DOI: http://dx.doi.org/10.5334/bar.g. License: CC-BY 4.0.

Bilgi ve İletişim Teknolojileri Kurumu, (2017). Elektronik Haberleşme Sektörüne İlişkin İl Bazında Yıllık Haber Bülteni, https://www.btk.gov.tr/File/?path=ROOT\%2f1\%2fDocuments\%2fSayfalar\%2fIl_Istatistikleri\%2fEhs yib_\%282011-2016\%29.pdf

Bolat, Y.̇̀., Aydemir, M., Karaman, S. (2017). Uzaktan Eğitim Öğrencilerinin Öğretimsel Etkinliklerde Mobil İnternet Kullanımlarının Teknoloji Kabul Modeline Göre İncelenmesi. Gazi Üniversitesi Eğitim Fakültesi Dergisi, 37(1), 63-91.

Chae, M. ve Kim, J. (2003). What's So Different About the Mobile Internet?, Communications of the ACM Mobile Computing Opportunities and Challenges. 46(12), 240-247.

Chatterjee, A. (2017). Customer Preference of Mobile Apps in W.B: Demographic Study. International Journal of Commerce and Management Research. 60-64. http://www.managejournal.com/up/conference/20170210155146.pdf (Erişim Tarihi:24.09.2017)

Chen, Z., Dubinsky, A.J. (2003). A conceptual model of perceived customer value in e-commerce: a preliminary investigation. Psychology \& Marketing, 23(4), 323-347.

Cheng, T.C.E., Lam, D.Y.C., Yeung, A.C.L. (2006). Adoption of internet banking: An empirical study in Hong Kong. Decision Support Systems, 42, 1558-1572.

Çakmak, T. ve Yalçın, H. (2013). Üniversite Öğrencilerinin Mobil Teknoloji Kullanımı: Hacettepe Üniversitesi Bilgi ve Belge Yönetimi Bölümü Örneği. Hacettepe Üniversitesi Türkiyat Araştırmaları Dergisi, 18, 47-61.

Davis, F.D. (1989). Perceived Usefulness, Perceived Ease of Use, and User Acceptance of Information Technology. MIS Quarterly, 13(3), 319-340.

Durak Batıgün, A. ve Kılıç, N. (2011). İnternet Bağımlılığı ve Kişilik Özellikleri, Sosyal Destek, Psikolojik Belirtiler ve Bazı Sosyo-Demografik Değişkenler Arasındaki İlişkiler. Türk Psikoloji Dergisi, 26(67), 1-10.

Gao, S., Krogstie, J., Siau, K. (2011). Developing an Instrument Measure the Adoption of Mobile Services", Mobile Information Systems, 7(1), 45-67.

Gerpott, T.J., May, S., Nas, G. (2016). The impact of mobile Internet on mobile Voice usage: A two-level analysis of mobile communications Customers in a GCC country. Information \& Management, pp. 1-13, http://dx.doi.org/10.1016/j.im.2017.02.003

Jenaro, C., Flores, N., Gómez-Vela, M., González-Gil, F., Caballo, C. (2007). Problematic Internet and CellPhone Use: Psychological, Behavioral, and Health Correlates. Addiction Research and Theory, 15(3), 309-320. 
Jones, S., Johnson-Yale, C., Millermaier, S., Perez, F.S. (2009). Everyday Life Online: U.S. College Students' Use of The Internet. First Monday, 14 (10).

Kim, H.W., Chan, H.C., Gupta, S. (2007). Value-based Adoption of Mobile Internet: An empirical investigation. Decision Support Systems, 43(1), 111 -126.

Klein Gröppel, A., Koenigstorfer, J. (2007). New insights in to the acceptance of mobile internet services: a mixed-method approach. International Journal of Internet Marketing and Advertising, 4(1), 72-92.

Koç, T., Turan, A.H. (2014). Mobil SABíS Kabul ve Kullanımı: Sakarya Üniversitesinde Ampirik Bir Değerlendirme. Bilgi Ekonomisi ve Yönetimi Dergisi, 9(2), 163-175.

Lee, W.J., Kim, T.U., Chungc J.Y. (2002). User Acceptance of the Mobile Internet. M-Business 2002. (2002, 8-9 Haziran). http://citeseerx.ist.psu.edu/viewdoc/download?doi=10.1.1.20.573 \&rep=rep1\&type=pdf (24.09.2017).

Ramirez-Correa, P.E., Rondan-Cataluña, F.J., Arenas-Gaitán, J. (2015). Predicting behavioral intention of mobile Internet usage. Telematics and Informatics, 32, 834-841.

Ratchford, B.T., Lee, M.S., Talukdar, D. (2003). The impact of the internet on information search for automobiles. Journal of Marketing Research. 40 (2), 193-209.

Roostika, R. (2012). Mobile Internet Acceptance among University Students: A Value-based Adoption Model. International Journal of Research in Management \&Technology. 2(1), 21-27.

Shin, Y.M., Lee, S.C., Shin, B., Lee, H.G. (2010). Examining influencing factors of post-adoption usage of mobile internet: Focus on the user perception of supplier-side attributes. Information Systems Frontiers, 12(5), 595-606.

Smith, R., Deitz, G., Royne, M.B., Hansen, J.D., Grünhagen, M., Witte, C. (2013). Cross-cultural examination of online shopping behavior: A comparison of Norway, Germany, and the United States. Journal of Business Research, 66, 328-335.

Şıklar, E., Tunalı, D., Gülcan, B. (2015). Mobil İnternet Kullanımının Benimsenmesinde Yakınsama Faktörüyle Teknoloji Kabul Modeli, Anadolu Üniversitesi Sosyal Bilimler Dergisi, 15(2), 99-110.

Uğur, N.G., Turan, A.H. (2015). Üniversite Öğrencilerinin Mobil Uygulamaları Kabulü ve Kullanımı: Sakarya Üniversitesi Örneği. İnternet Uygulamaları ve Yönetimi, 6(2). 63-79

Venkatesh, V., Davis, F.D. (2000). A Theoretical Extension of the Technology Acceptance Model: Four Longitudinal Field Studies. Management Science, 46 (2), 186-204.

Vlachos, P.A., Vrechopoulos, A.P. (2008). Determinants of behavioral intentions in the mobile internet services market. Journal of Services Marketing, 22(4), 280-291.

Walmsley, A.D., White, D.A., Eynon, R., Somerfield, L. (2003). The Use of Internet Within a Dental School. European Journal of Dental Education, 7(1), 27-33.

We Are Social and Hootsuite, (2017). Digital in 2017 Global Overvie, https://wearesocial.com/specialreports/digital-in-2017-global-overview (08.09.2017) 